\title{
Will Different Bonus Size Encourages to Complete a Difficulty Target?
}

\author{
Yenni Agustina ${ }^{1}$ \\ \{yennidzaaki83@gmail.com ${ }^{1}$ \} \\ Accounting Department, University of Lampung, Sumantri Brojonegoro Street No.1, Bandar Lampung, \\ Indonesia $^{1}$
}

\begin{abstract}
This analysis is based on the assumption that there are already income disparities that the bonus is not always a good instrument to support one 's success because a manager needs to do a self-actualization factor, by testing a different bonus number for each experimental test as an input for the study, the novelty of this research is. This study used a $2 \times 2$ between-subjects design experimental method. The results show that in completing difficult tasks, a low bonus will strengthen the relationship between benefit and danger encounters, while a larger bonus will strengthen the relationship between loss and conditions of danger. It can be inferred on the basis of these findings that incentives are one of the logical factors that motivate someone to perform demanding tasks.
\end{abstract}

Keywords: Bonus, Difficulty Target, Accounting Information, Situasional Information.

\section{Introduction}

Targets have a significant role in almost all businesses in management control schemes [2][4]. This is because if they reach the predetermined goals, the target is closely linked to the incentive payments that managers would earn [1], [5]-[9]. The complexity aim [2], [3] is one aspect of the targeting, which typically includes risks that will affect a person in achieving goals [10], [11]. As predictors of difficult task success, this research aims to empirically evaluate accounting information, situational information, and bonuses. This research adds to the literature on accounting. Second, this analysis uses primary data collected from causality testing such that the findings obtained can support the hypothesis that incentives can be used as a method to enhance employee efficiency in terms of management control systems. In addition, this research helps to provide input to the management of the company to pay attention to the compensation system that would be provided to managers.

\section{Literature Review}

Contextual situations are things that often influence someone to complete demanding tasks or goals [10]. The theory of prospects is a theory which explains decision-making in difficult or unpredictable circumstances [12]. The idea defines the mentality of those willing to take chances or vice versa. The attitude of one to complete tasks, however, is, of course, profoundly affected by one's attitude of rationality. Of course, this is in line with Weber 's philosophy of rationality. This theory 
explains that fair factors affect the rational behavior of an individual [13], [14]. Both of these ideas make it clear that, whether it is founded on logical considerations, solving impossible tasks would be solved. Therefore, some researchers claim that, as part of a management control system tool, the need for external motivation such as incentive payments to inspire executives to complete challenging tasks ([5], [15]-[17]. The findings indicate that rewards or promotions may enhance the success of managers in achieving demanding tasks or goals [1], [2], [18]. This is due to the considerations of reason of an individual. However, when the objectives to be accomplished are in a difficult situation than in an ordinary situation, the bonus role as moderator will further enhance results. This is because when they are in a difficult yet resolvable goal, someone will feel challenged [1], [2], [17], [19], [20]. Based on the theory and previous research, the hypothesis that the researcher proposes is:

$\mathrm{H}_{\mathrm{a} 1}$ : In a situation where accounting information is profitable and there is a threat, the performance of solving targets difficult will increase when moderated by bonuses.

Referring to the rationality principle and the prospect theory that when a person is in a situation that is considered logical or rational, a person would be inspired to complete a difficult task. Bonuses as a management control system instrument can boost the efficiency of managers when the goals to be accomplished are not long in time ([1]. This is very rational because managers will consider other variables that can influence their performance to complete the task such that managers can consider the amount of bonus they earn to boost performance in difficult decisions [1], [5]. Therefore, based on this explanation, the hypothesis suggested by the researcher is:

$\mathrm{H}_{\mathrm{a} 2}$ : The amount of the bonus will strengthen the relationship between loss and threat interactions on the completion of tasks difficult.

\section{Methodology and Data Analysis}

\section{Design Research}

the study used a laboratory experimental method using a $2 \times 2$ factorial design between subjects.

\section{Subject}

The subjects of this study were undergraduate students, amounting to 65 people, 33 male, and 32 female.

\section{Check Manipulation}

Manipulation is carried out on the independent variables of accounting information, namely profit, situational information, namely opportunities and threats and bonuses as measured by high and low.

\section{Procedure}

The experimental procedure was carried out by means that the subject in each cell would be given information about accounting information and situational information in accordance with the manipulation treatment in each cell. After the subject is trapped into manipulation, then the subject receives the first task, which is a game of assignments that must be completed within 2 minutes, if the subject is able to complete the first given task within the specified time, the respondent will be given a prize of IDR 5000 to present a 10 million. In the second stage, the subject is given the task 
again to complete the same game and within the same time period with a bonus of IDR 50,000 to represent a 100 million bonus for those who can complete the task within the specified time. After the experimental testing is carried out, the last step is carried out, namely by performing a manipulation check. Manipulation check is done by asking several questions in the form of differences in performance before and after being given treatment, namely below average, average, and above average. Based on the data entered, it is in a condition of profit and loss as well as in a condition of opportunities and threats with a value of 1.37 and 2.60 respectively with a significance level of

$\mathrm{p}<0.015$.

\section{Research Result and Discussion}

The first test conducted was to look at the interaction of accounting and situational information without being influenced by bonuses. Based on this test, the results obtained are:

Table 1. Anava Test

\begin{tabular}{lccc}
\hline & Mean Square & F & Sig. \\
\hline Accounting information & 5.37 & 7.863 &, 007, \\
situational information &, 193 &, 279, & 605 \\
accounting information* &, 667 &, 978 &, 337 \\
situational information & & & \\
Error, & 671 & &
\end{tabular}

Based on the table it appears that the interaction of the two is not significant so it is necessary to strengthen the interaction moderating variable both of these variables.

\section{Moderation Test}

The first test conducted is to see the interaction between accounting information and situational information in completing difficult tasks with low bonuses as moderation. Based on the results of Lavene's test, the results were Sig. 0.000 with a magnitude of F, namely 7.391, which means that the ANOVA assumption test is not fulfilled. However, even so the ANOVA test can still be continued because the ANOVA is still robust so that the ANOVA test can be carried out with the following results, namely:

Table 2.Anava Test

\begin{tabular}{llll}
\hline Information & Mean Square & F & Sig. \\
\hline Accounting & 7.391 & 25.353, & 000 \\
Information & & & \\
situational & 1.38 & 4.65 &, 030 \\
Bonus & 4.556 & 15.71, & 000 \\
AI*SI* & 1.294 & 4.439 &, 000 \\
Bonus10m & & & \\
Error, & 292 & & \\
\hline
\end{tabular}

From the above table, the outcomes got are as per the following every factor, to be specific bookkeeping data, situational data, and rewards impacts the consummation of troublesome targets. With the extent of the F esteem in every factor, in particular 25.353 for data, 4.65 for situational, 
and 15.71 for the reward. The centrality estimation of every factor is underneath 0.05 . So it very well may be presumed that there is an immediate impact on every factor. In view of the aftereffects of the collaboration test, there is a directing impact of rewards on the cooperation between accounting information and situational factors.

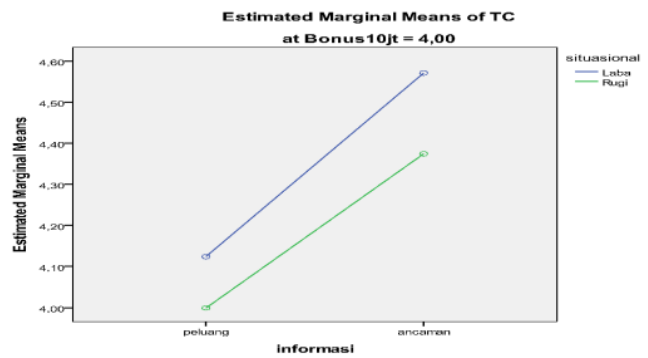

Fig 1. Bonus Rp 10.000.000

In the image above, it very well may be seen that in a benefit condition despite the fact that there is a danger it will impact somebody to finish a troublesome assignment when directed by the reward. Scientists presume that this outcome is because of the reasonable thinking about the director that despite the fact that there is a danger when the benefit is in condition, it will make it simpler for them to finish the objective despite the fact that they get an inadmissible reward for them. The help of the elective speculation, obviously, bolsters the hypothesis of soundness, which is a hypothesis which expresses that somebody will settle on choices following their discernment.

\section{Interaction Test with 10x Bonus as Moderation}

Based on the results of the ANOVA test, the following results are obtained:

Table 3. Anava Test

\begin{tabular}{llll}
\hline Information & Mean Square & F & Sig. \\
\hline Accounting information & 7.952 & 17.741 & information,000 \\
situational information & 3.389 & 7.561 &, 008 \\
Bonus 100m & 1.934 & 4.315 & Bonus,000 \\
Information accounting* Situational * &, 448 & 17.741, & 000 \\
Bonus 100jt & & & \\
Error & 7.952 & & \\
\hline
\end{tabular}

Based on the table, it can be seen that the $F$ value of each variable is 17.741 and 7.561 with a significance level for each variable, namely 0.00 and 0.008 below the 0.05 value. Also, based on the interaction test of the two with a 10 -fold bonus as moderation, the $\mathrm{F}$ value is 4.351 with a significance level of 0.000 below 0.05 . Thus it can be concluded that the interaction between information and situational variables will influence a person to complete a difficult task when moderated by a high bonus, the variability of the magnitude of this influence can be seen from the adjusted $R$ square value of $39.2 \%$. 


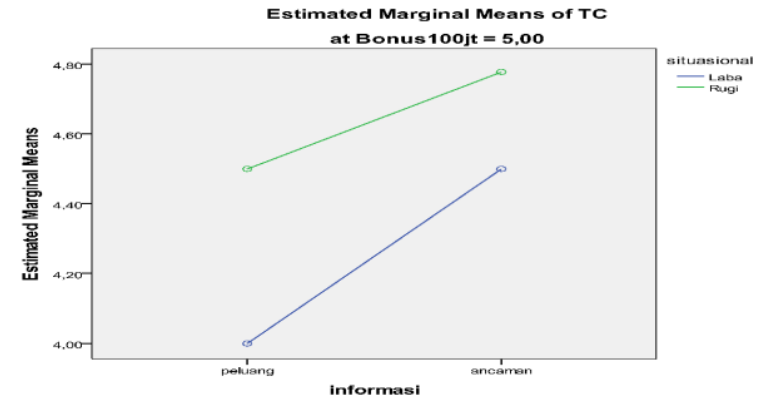

Fig 2. Bonus Rp 100.000.000

Based on the picture above, it can be seen that in conditions of high loss and threat, one's performance to complete difficult tasks will increase when moderated by high bonuses. This of course supports the prospect theory and rationality that there are certain considerations that require a person to make certain decisions.

\section{Conclusion}

Based on the research objectives, it can be concluded that someone will act when there is a rational basis that influences them. Based on testing of the two bonuses offered with various conditions, it can be concluded that bonuses can be a tool to encourage someone to complete tasks.

\section{Implications / Limitations and Suggestions for Further Research}

This research is a theoretical test that can have scientific enrichment in the field of accounting, especially the management control system, that the bonus system is so strong enough to encourage someone to improve performance but there are other factors which affect managers to complete the task. Therefore, further research is needed based on what things managers can help improve performance. For future research, it is advisable to separate managers who still view bonuses as important, casual, and unimportant.

\section{References}

[1] I. Ioannou, S. X. Li, and G. Serafeim, "The effect of target difficulty on target completion: The case of reducing carbon emissions," Account. Rev., vol. 91, no. 5, pp. 1467-1492, 2016, doi: 10.2308/accr-51307.

[2] M. C. Arnold and M. Artz, "Target difficulty, target flexibility, and firm performance: Evidence from business units' targets," Accounting, Organ. Soc., 2015, [Online]. Available: https://www.sciencedirect.com/science/article/pii/S0361368214001032.

[3] R. H. Chenhall, "Management control systems design within its organizational context : findings from contingency-based research and directions for the future," vol. 28, pp. 127168, 2003.

[4] M. K. Hirst and S. M. Lowy, "The linear additive and interactive effects of budgetary goal difficulty and feedback on performance," Accounting, Organ. Soc., 1990, [Online]. 
Available: https://www.sciencedirect.com/science/article/pii/036136829090026Q.

[5] R. Alan Webb, M. G. Williamson, and Y. Zhang, "Productivity-target difficulty, targetbased pay, and outside-the-box thinking," Account. Rev., vol. 88, no. 4, pp. 1433-1457, 2013, doi: 10.2308/accr-50436.

[6] J. Bisbe and R. Malagueño, "The choice of interactive control systems under different innovation management modes," Eur. Account. Rev., 2009, [Online]. Available: https://www.tandfonline.com/doi/abs/10.1080/09638180902863803.

[7] S. E. Bonner and G. B. Sprinkle, "The effects of monetary incentives on effort and task performance : theories, evidence, and a framework for research," vol. 27, pp. 303-345, 2002.

[8] M. Covaleski, J. H. Evans, J. Luft, and M. D. Shields, "Budgeting Research: Three Theoretical Perspectives and Criteria for Selective Integration," Handbooks of Management Accounting Research. 2006, doi: 10.1016/S1751-3243(06)02006-2.

[9] S. K. Widener, "Associations between strategic resource importance and performance measure use: The impact on firm performance," Manag. Account. Res., vol. 17, no. 4, pp. 433-457, 2006, doi: 10.1016/j.mar.2005.10.002.

[10] D. Forlani, "Risk and Rationality: The Influence of Decision Domain and Perceived Outcome Control on Managers' High-risk Decisions," J. Behav. Decis. Mak., vol. 15, no. 2, pp. 125-140, 2002, doi: 10.1002/bdm.406.

[11] G. McNamara and P. Bromiley, "Risk and return in organizational decision making," Acad. Manag. J., vol. 42, no. 3, pp. 330-339, 1999, doi: 10.2307/256923.

[12] B. Y. D. Kahneman and A. Tversky, "Chapter 6," vol. 47, no. 2, pp. 263-291, 1979.

[13] D. N. Levine, "The Continuing Challenge of Weber's theory of Rational Action," Econ. Soc. 2000, pp. 101-126, 2005.

[14] E. U. Weber and R. A. Milliman, "Perceived risk attitudes: Relating risk perception to risky choice," Manage. Sci., vol. 43, no. 2, pp. 123-144, 1997, doi: 10.1287/mnsc.43.2.123.

[15] S. W. Anderson, H. C. Dekker, and K. L. Sedatole, "An empirical examination of goals and performance-to-goal following the introduction of an incentive bonus plan with participative goal setting," Manage. Sci., vol. 56, no. 1, pp. 90-109, 2010, doi: 10.1287/mnsc.1090.1088.

[16] B. S. Bell and W. J. Kozlowski, "Goal orientation and ability: Interactive effects on selfefficacy, performance, and knowledge.," J. Appl. Psychol., 2002, [Online]. Available: https://psycnet.apa.org/doiLanding?doi=10.1037/0021-9010.87.3.497.

[17] C. M. Lau and K. Roopnarain, "The effects of nonfinancial and financial measures on employee motivation to participate in target setting," Br. Account. Rev., vol. 46, no. 3, pp. 228-247, 2014, doi: 10.1016/j.bar.2014.02.006.

[18] B. Gerhart, S. L. Rynes, and I. S. Fulmer, "6 Pay and Performance: Individuals, Groups, and Executives," Acad. Manag. Ann., vol. 3, no. 1, pp. 251-315, 2009, doi: $10.1080 / 19416520903047269$.

[19] M. Arnold and M. Artz, "The use of a single budget or separate budgets for planning and performance evaluation," Accounting, Organ. Soc., 2019, [Online]. Available: https://www.sciencedirect.com/science/article/pii/S0361368218303234.

[20] M. Mate, "Target Setting in Multi-Divisional Organizations," vol. 30, no. 3, pp. 13-27, 
2018, doi: 10.2308/jmar-52159.

[1] I. Ioannou, S. X. Li, and G. Serafeim, "The effect of target difficulty on target completion: The case of reducing carbon emissions," Account. Rev., vol. 91, no. 5, pp. 1467-1492, 2016, doi: 10.2308/accr-51307.

[2] M. C. Arnold and M. Artz, "Target difficulty, target flexibility, and firm performance: Evidence from business units' targets," Accounting, Organ. Soc., 2015, [Online]. Available: https://www.sciencedirect.com/science/article/pii/S0361368214001032.

[3] R. H. Chenhall, "Management control systems design within its organizational context : findings from contingency-based research and directions for the future," vol. 28, pp. 127 $168,2003$.

[4] M. K. Hirst and S. M. Lowy, "The linear additive and interactive effects of budgetary goal difficulty and feedback on performance," Accounting, Organ. Soc., 1990, [Online]. Available: https://www.sciencedirect.com/science/article/pii/036136829090026Q.

[5] R. Alan Webb, M. G. Williamson, and Y. Zhang, "Productivity-target difficulty, targetbased pay, and outside-the-box thinking," Account. Rev., vol. 88, no. 4, pp. 1433-1457, 2013, doi: 10.2308/accr-50436.

[6] J. Bisbe and R. Malagueño, "The choice of interactive control systems under different innovation management modes," Eur. Account. Rev., 2009, [Online]. Available: https://www.tandfonline.com/doi/abs/10.1080/09638180902863803.

[7] S. E. Bonner and G. B. Sprinkle, "The effects of monetary incentives on effort and task performance : theories, evidence, and a framework for research," vol. 27, pp. 303-345, 2002.

[8] M. Covaleski, J. H. Evans, J. Luft, and M. D. Shields, "Budgeting Research: Three Theoretical Perspectives and Criteria for Selective Integration," Handbooks of

Management Accounting Research. 2006, doi: 10.1016/S1751-3243(06)02006-2.

[9] S. K. Widener, "Associations between strategic resource importance and performance measure use: The impact on firm performance," Manag. Account. Res., vol. 17, no. 4, pp. 433-457, 2006, doi: 10.1016/j.mar.2005.10.002.

[10] D. Forlani, "Risk and Rationality: The Influence of Decision Domain and Perceived Outcome Control on Managers' High-risk Decisions," J. Behav. Decis. Mak., vol. 15, no. 2, pp. 125-140, 2002, doi: 10.1002/bdm.406.

[11] G. McNamara and P. Bromiley, "Risk and return in organizational decision making," Acad. Manag. J., vol. 42, no. 3, pp. 330-339, 1999, doi: 10.2307/256923.

[12] B. Y. D. Kahneman and A. Tversky, "Chapter 6," vol. 47, no. 2, pp. 263-291, 1979.

[13] D. N. Levine, "The Continuing Challenge of Weber's theory of Rational Action," Econ. Soc. 2000, pp. 101-126, 2005.

[14] E. U. Weber and R. A. Milliman, "Perceived risk attitudes: Relating risk perception to risky choice," Manage. Sci., vol. 43, no. 2, pp. 123-144, 1997, doi: 10.1287/mnsc.43.2.123.

[15] S. W. Anderson, H. C. Dekker, and K. L. Sedatole, "An empirical examination of goals and performance-to-goal following the introduction of an incentive bonus plan with participative goal setting," Manage. Sci., vol. 56, no. 1, pp. 90-109, 2010, doi: 10.1287/mnsc.1090.1088.

[16] B. S. Bell and W. J. Kozlowski, "Goal orientation and ability: Interactive effects on self- 
efficacy, performance, and knowledge.," J. Appl. Psychol., 2002, [Online]. Available: https://psycnet.apa.org/doiLanding?doi=10.1037/0021-9010.87.3.497.

[17] C. M. Lau and K. Roopnarain, "The effects of nonfinancial and financial measures on employee motivation to participate in target setting," Br. Account. Rev., vol. 46, no. 3, pp. 228-247, 2014, doi: 10.1016/j.bar.2014.02.006.

[18] B. Gerhart, S. L. Rynes, and I. S. Fulmer, "6 Pay and Performance: Individuals, Groups, and Executives," Acad. Manag. Ann., vol. 3, no. 1, pp. 251-315, 2009, doi: 10.1080/19416520903047269.

[19] M. Arnold and M. Artz, "The use of a single budget or separate budgets for planning and performance evaluation," Accounting, Organ. Soc., 2019, [Online]. Available: https://www.sciencedirect.com/science/article/pii/S0361368218303234.

[20] M. Mate, "Target Setting in Multi-Divisional Organizations," vol. 30, no. 3, pp. 13-27, 2018, doi: 10.2308/jmar-52159. 